\title{
Crop planning based on rainfall variability for Bastar region of Chhattisgarh, India
}

\author{
ADIKANT PRADHAN ${ }^{*}$, T. CHANDRAKAR ${ }^{1}$, S.K. NAG ${ }^{2}$, A. DIXIT ${ }^{3}$ and S.C. MUKHERJEE ${ }^{2}$ \\ ${ }^{1}$ AICRPDA, ${ }^{2}$ S. G. CARS, IGKV, Jagdalpur, Chattisgarh 494 001, \\ ${ }^{3}$ ICAR-National Institute of Biotic Stress Management, Raipur, Chattisgarh 492012, \\ *Corresponding author:adi19agro@gmail.com
}

\begin{abstract}
Analysis of long-term rainfall data (1986-2018) of Bastar region revealed decreasing trend in total quantum of annual rainfall with varying frequency and distribution. The quantity of winter and summer rains decreased drastically during 2008-18 as compared to earlier two decades (1986-96 and 19972007). SW monsoon rain of 2008-18 was more than past two decades, whereas NE monsoon rain changed much in quantity except during 1997-2007. During 1986-96, the pre-monsoon shower was received in April, but later two decades the shower was received in May, which supports for summer ploughing and dry aerobic seeding. The cropping period almost synchronized between 22-43 standard meteorological week (SMW) reaching $93.11 \mathrm{~mm}$ per week as maximum rainfall. As the probability of 20 $\mathrm{mm}$ rainfall decreased from 75 to $50 \%$, the crop yield got reduced by $30 \%$. The mid-land rice with a probability of 13.47 to $16.07 \mathrm{~mm}$ rain per week supported growth phase during 17-21SMW. Whereas, upland rice maturing in 90-100 days could avoid dry spells, if the rice is managed by conservation furrows at the time of sowing. The summer ploughing is preferred with more than $40 \mathrm{~mm}$ rain in single day during March to April for mitigating dry spells. On the other hand, preparatory tillage and sowing were performed together in support of ripening niger and horsegram under probability of 75,50 and $25 \%$ rain through crop planning. Maize and small millets reduced yield significantly when rainfall reached $75 \%$ deficit, whereas $25 \%$ deficit rain did not affect the yields.
\end{abstract}

Key words: Rainfall, trend analysis, crop planning, seasonal rainfall, crop management and rainfed ecosystem.

Rainfall is crucial in agricultural planning for rainfed region which completely depends on rainfall and its distribution in any annual calendar. Variability in rainfall includes onset, distribution and cessation during the year which decides the agricultural operations. On other hands, quantum of rainfall might be same but its distribution varies according to rainfall events and crops undergo insufficient growth. The change in rainfall can't be assessed easily due process of cloud formation and raining is unpredictable, but long-term rainfall analysis could be scaled up the planning of agriculture in rainfed region.

Rainfall is the single most important factor in crop planning in rain-fed ecologies. Around $60 \%$ of the Indian agriculture is rain dependent, diverse, complex, underinvested, risky, distress prone and vulnerable; with diverse climate. India has a high spatial and temporal variability in rainfall and temperature (Rao et al., 2010).Dry spells in rainfed agriculture are the general features in India. The perception of drought varies from one region to another depending upon normal climatic conditions, available water resources and agricultural practices (Pandey and Bhandari,
2007). Intra-seasonal variability of rain has been further compounded due to increase in frequency and intensity of the rainfall and weather events under climate change scenario. Rainfall, being considered as the prime input for agriculture has its own erratic behaviour in terms of amount and distribution for better crop planning. Rainfall variability with time and space influences the agricultural productivity and sustainability of a region, as opined by Rockstrom and Falkenmark (2000). Rainfall analysis for crop planning was carried out in different regions of the country as reported by Agarwal (2000). The information on annual, decadal and seasonal rainfall of a region is useful for field preparation, seeding, irrigation, fertilizer application and overall in field crop planning. The pre-monsoon rains can be utilized for summer ploughing or seedbed preparation as well as raising rice seedlings in lowland during 20 to $22^{\text {nd }}(20-30$, May) SMW (Rai and Singh, 2009).

Climate change is very likely to have a major impact on hydrological cycle and consequently on available water resources, flood and drought frequencies, natural ecosystems, society and the economy (Ramos, 2001). 
Similarly pulse and oilseed crops are also influenced by vagaries of rainfall from sowing to harvesting either by excess moisture or less moisture condition. The Bastar region is a typical rainfed region and different crops are grown on various land forms (upland, midland and lowland). On the basis of rainfall scenario, crop planning of cereals, pulses and oilseeds can be performed with yield advantage. Arhar, urd and moong are very much affected by rainfall trend in the region due to early down pour, mid-season and terminal drought. Especially the arhar crop falls under terminal drought whereas remaining two crops i.e., urd and moong coincide with heavy shower and waterlogged condition. This harsh situation changed the land use pattern of the region. Uplands were cultivated with cereals, pulses and oilseeds. Now the uplands becoming fallow due to moisture stress in mid-season along with low production. Similar situation also expanded with mid-land and low-land in rabi season. The existing scenario of the long-term rainfall has been considered under study to fulfil the objective of crop planning based on rainfall trend.

\section{MATERIALS AND METHODS}

\section{Data collection}

Rainfall data of 32 years (1986-2018) were collected from Meteorological Observatory, S.G. College of Agriculture $\&$ Research Station, IGKV, Jagdalpur. The collected data were further divided in three segments; (i) first decade (1986-1996), (ii) second decade (1997-2007) and (iii) third decade (2008-2018) along with variability analysis of rainfall done to draw valid conclusion.

\section{Data analysis}

The data on rainfall were analyzed on annual, seasonal and decadal basis for the entire series under the study. The season was decided as per IMD classification, i.e., monsoon season from June-September $\left(23^{\text {rd }}\right.$ to $39^{\text {th }}$ meteorological week), post-monsoon season from October-November $\left(40^{\text {th }}\right.$ to $49^{\text {th }}$ meteorological week), winter season from DecemberFebruary ( $49^{\text {th }}$ to $9^{\text {th }}$ meteorological week) and summer season from March-May ( $10^{\text {th }}$ to $22^{\text {nd }}$ meteorological week $)$. Time series analysis was performed and statistical significance of trends in meteorological data was examined using standard Mann-Kendall test statistics (Libiseller and Grimall, 2002). The non-parametric Mann-Kendall (M-K) statistical rank test which is widely used in climate research employed to find out fluctuations and presence of trend in time series data of weather. The statistical significance is tested at $95 \%$ level. The M-K rank statistics ( $\mathrm{t}$ ) is computed as:

$$
\mathrm{t}=\frac{4 \sum \mathrm{ni}}{N(N-1)}-1
$$

Where, $\mathrm{n}$ is the number of data values larger than the $\mathrm{i}^{\text {th }}$ value, subsequent to its position in the series and $\mathrm{N}$ is the total number of data in the series.

\section{RESULTS AND DISCUSSION}

\section{Rainfall variability}

In last three decades, Bastar region received more than $1000 \mathrm{~mm}$ annual rainfall whereas the years 1997 and 2002 received less than $1000 \mathrm{~mm}$. In contrast, two peculiar years 1990 and 2010 had more than $2000 \mathrm{~mm}$ rainfall. The long-term rainfall maintained the annual trend of 1400 $1500 \mathrm{~mm}$. Weekly rainfall distribution was divided in three parts as 1 to 23 (I), 24to 36 (II) and 37to 50 (III) standard meteorological weeks (SMW) in which mean, standard deviation and co-efficient of variation were highly fluctuated in I and III part. The daily rainfall was studied into decadal distributions viz., 1986-96, 1997-2007 and 2008-18 for effective analysis to know the variation in quantity and frequency of rainfall. These quantity and variation directly influenced regional agriculture because whole region adopt the rainfed agriculture. Pre-monsoon shower were received in April during 1986-96 which was shifted to May in later two decades.

Although, rainfall pattern showed much variation in June-October during 1997-2007 compared to 1986-96 and 2007-18 and decreasing trend of rainfall was observed in November-December during 1986-96. The increasing trend of winter rainfall was noticed with 1907-07 whereas in recent decade (2008-18), the winter rainfall reduced quantity. In consideration to seasonal rainfall, summer rain increased with decreasing NE monsoon rain during 2008-18 (Table 1 and Fig. 1). Hence, summer shower influenced SW monsoon by increasing quantity in 1986-96 and 2008-18.

The seasonal variation in rainfall showed slight variation in SW monsoon (June-September) but remaining seasons did not vary in consideration to quantity. Rainfall of winter monsoon was recorded decreasing trend from $21.27 \mathrm{~mm}$ to $11.25 \mathrm{~mm}$ monthly regardless the decades. The change in summer rainfall via pre-monsoon shower influenced more the dry seeding in April and May coupled with summer ploughing. Due to the change in pattern of summer rain the transplanting was shifted to direct seeding under suggested crop planning. Similar result was found for 


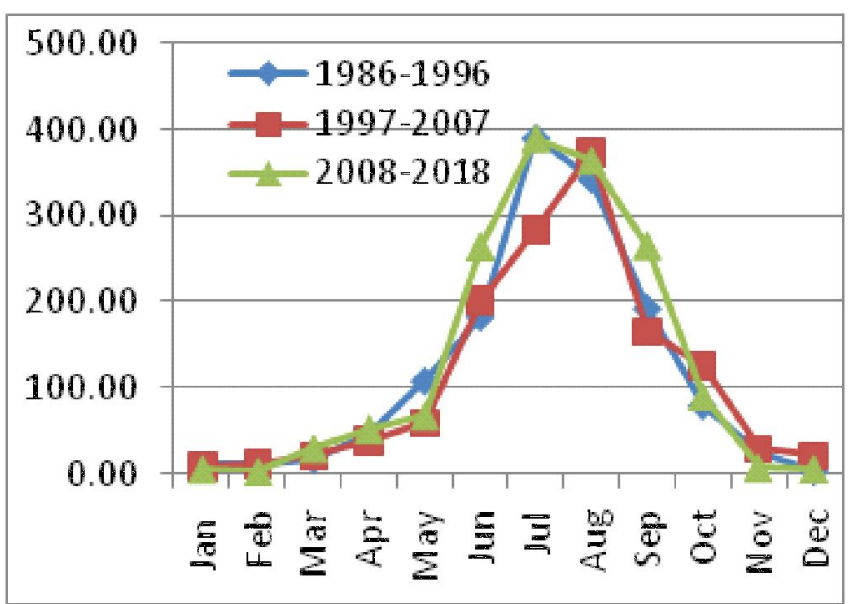

a. Decadal rainfall $(\mathrm{mm})$

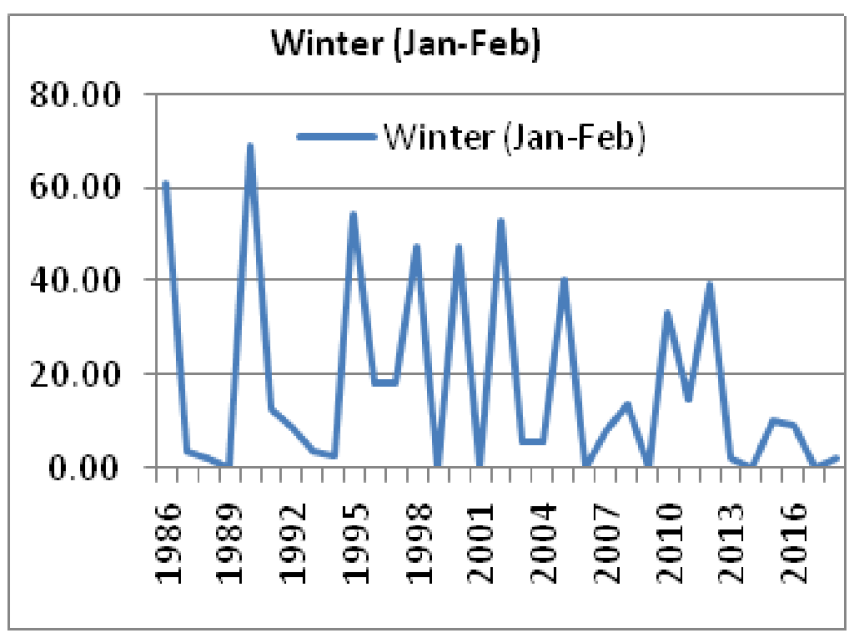

c. Winter rainfall (MM)

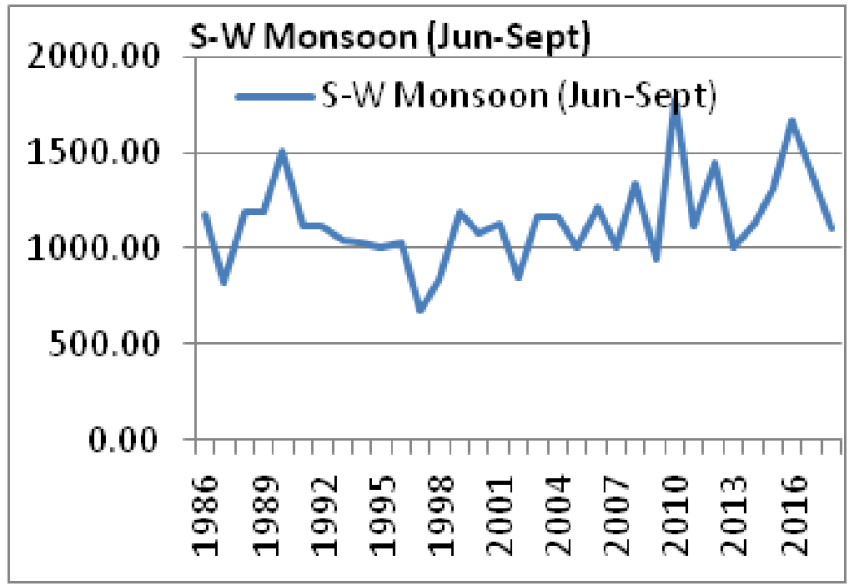

e. South-western monsoonal rainfall $(\mathrm{mm})$

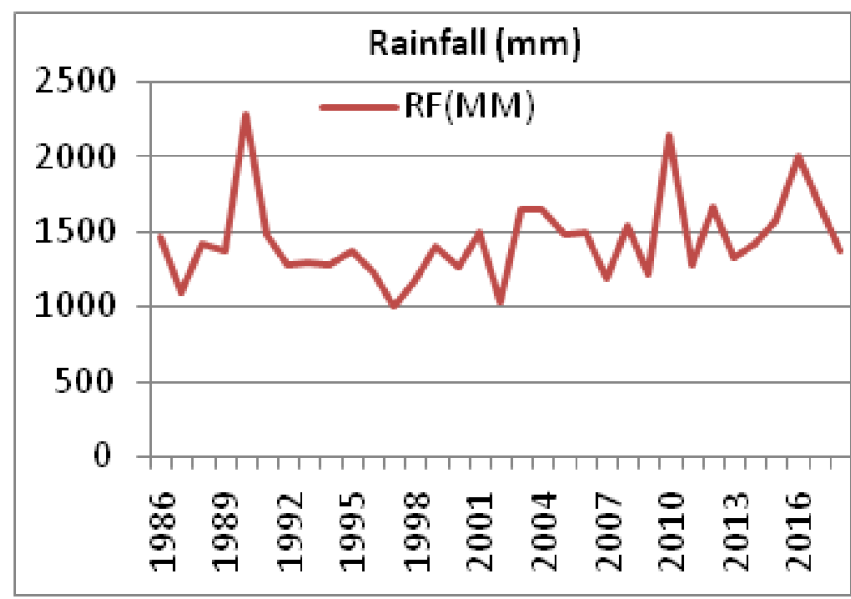

b. Annual rainfall (mm)

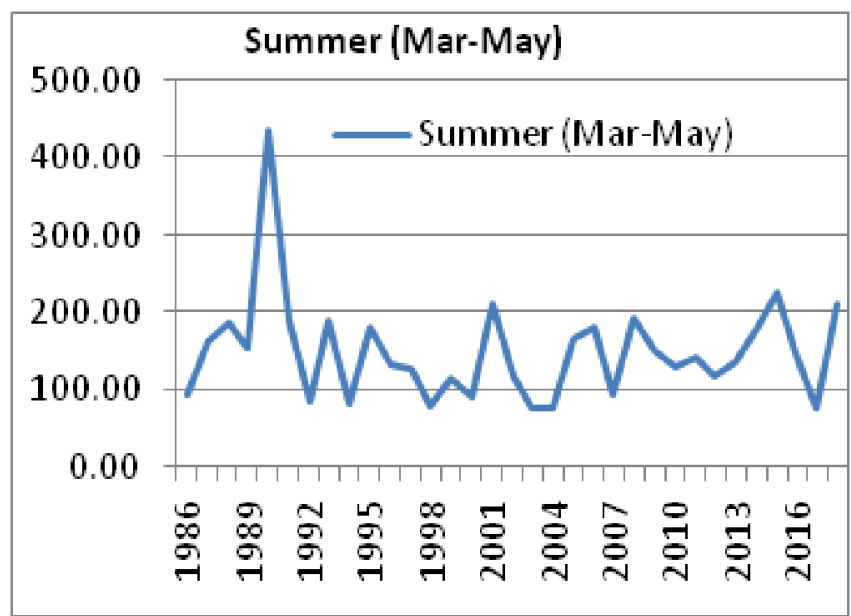

d. Summer rainfall $(\mathrm{mm})$

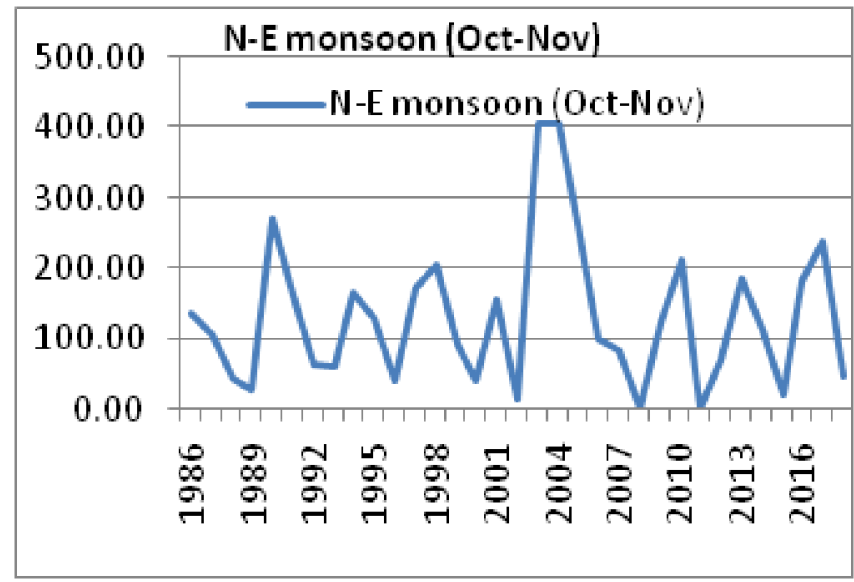

f. North-eastern monsoonal rainfall $(\mathrm{mm})$

Fig.1: Rainfall variability of decadal (a), annual (b), winter (c), summer (d), S-W monsoonal (e), N-Emonsoonal (f) of Bastar region during 1986 - 2018 
Table 1: Mann Kendall trend statistics (t) precipitation in decadal rainfall (mm)

\begin{tabular}{lllll}
\hline Season & \multicolumn{3}{c}{ Decadal rainfall $(\mathrm{mm})$} \\
& $1986-96$ & $1997-07$ & $2008-18$ & Mean \\
\hline Winter (Jan-Feb) & $21.27(+)$ & $20.41(-)^{*}$ & $11.25(-)^{*}$ & $17.64(-)^{*}$ \\
Summer (Mar-May) & $171.35(+)$ & $120.08(-)$ & $154.01(+)^{*}$ & $148.48(+)$ \\
S-W Monsoon (Jun-Sept) & $1110.67(+)^{*}$ & $1026.91(+)$ & $1288.92(+)^{*}$ & $1142.17(+)^{*}$ \\
N-E monsoon (Oct-Nov) & $109.03(+)^{*}$ & $175.73(-)$ & $107.68(-)^{*}$ & $130.81(-)$ \\
\hline
\end{tabular}

Where, $(+)$ shows increasing trend; (-) shows decreasing trend; *0.05 level of significance

summer monsoon by Kolli et al. (1992) and Jalota et al. (2013). On the other hand, NE monsoon rain is important for rabi season and the decreasing trend of NE monsoon rain shrinked drastically the rabi cropping due to lack of soil moisture under in rainfed cultivation (Table 2). The soil moisture was sustained longer with NE monsoon in rabi season during earlier decades. Sowing of rabi crops could be improved by seed priming and sowing with zero till (relay cropping).

\section{Effect of rainfall on crop planning}

Precipitation probability of 25,50 and $75 \%$ rain were analysed considering 32 years rainfall data. The probability of $75 \%$ with more than $20 \mathrm{~mm}$ weekly rainfall have been highly predicted during $24^{\text {th }}\left(11^{\text {th }}\right.$ June $-17^{\text {th }}$ June $)$ to $36^{\text {th }}\left(3^{\text {rd }}\right.$ Sept $-9^{\text {th }}$ Sept) SMWs. The continuous rain supports to kharif crops during these periods. The quantity of rainfall envisages to agricultural practices in maintaining optimum soil moisture till November for midland and lowland (Figure 1). The 32 -yeardata expressed that the occurrence of $20 \mathrm{~mm}$ rain was more between $22\left(28^{\text {th }}\right.$ May $-3^{\text {rd }}$ June $)$ to $41\left(8^{\text {th }}\right.$ Oct$14^{\text {th }} \mathrm{Oct}$ ) SMW. But, average rainfall was not more than 100 mm in a single week (Table 2). Rice, maize, millets, horsegram, sesame and niger were grown under prevailing scenario of rainfall and gave more yield than existing pattern. Sastri et al. (1999) also suggested similar trend of rainfall in crop planning for attaining higher yield of rainfed rice. When the probability of $20 \mathrm{~mm}$ rain was decreased from 75 to $50 \%$ the crops yield reduced by $30 \%$ (Kim et al., 2011). Whereas, $25 \%$ probability of $20 \mathrm{~mm}$ rain at mid kharif reduced the yield drastically even being lower than non-planned cropping.

\section{Effect of rainfall on tillage operations}

Existing cropping pattern depends on prevailing rainfall, tillage and landforms of Bastar region. The summer ploughing, preparatory tillage and sowing were performed in 52 SMW improved the yields by crop planning with long term data. On the other hand, rice is grown in special ecosystems like upland, midland, lowland and extreme lowland are affected by rainfall and slope and the situations could be leveraged through tillage and crops. The rice was sown early in $15-20^{\text {th }}$ May found better in obtaining higher yield than late sown rice (Table 3 ) and late sown rice associated with stagnation of rain water in mid-land and lowlands if delayed in sowing. The mean probabilities of 4.04 to $8.90 \mathrm{~mm}$ rain per week were found suitable for summer ploughing during 26 February to 8 April. Thus, summer ploughing enhances the soil moisture for rice in upland, midland and lowland eco-systems. But extreme lowland has shorter window of summer ploughing with 5.64 to $13.74 \mathrm{~mm}$ weekly rain from 19 March to 23 April, for which the summer ploughing followed by sowing was more feasible in term of yields in the rice ecosystems (Table 2).

Dry seeding requires summer rain which provides congenial condition locally called "Batar" for ploughing during April to May. The summer ploughing has been recommended for rice cultivation in midland and lowland because summer ploughing retains more soil moisture and later helps in preparatory tillage and sowing. The suggested crop planning was to avoid summer ploughing in other crops. The suggestion improved the probability of second crop in rabi season with applying summer ploughing. In contrast, the soil moisture did not last till December by escaping summer ploughing in rice-fallow system (Table 2). Tripathi (2012) found similar result with crop weather yield model tested with summer ploughing in different agroclimatic regions of Uttar Pradesh. As the condition delayed by 2 weeks, dry seeding was badly affected and farmers opted re-sowing in June or transplanting in July as contingent plan under delayed situation in rainfed farming (Prasad et al., 2014). In July month, probability of rain increases wetness in the fields enough. But later growing stages of rice encounter with dry spells during mid-season while vegetative and active tillering stages. This condition could be improved by summer ploughing in April-May to hold soil moisture (Table 2). 


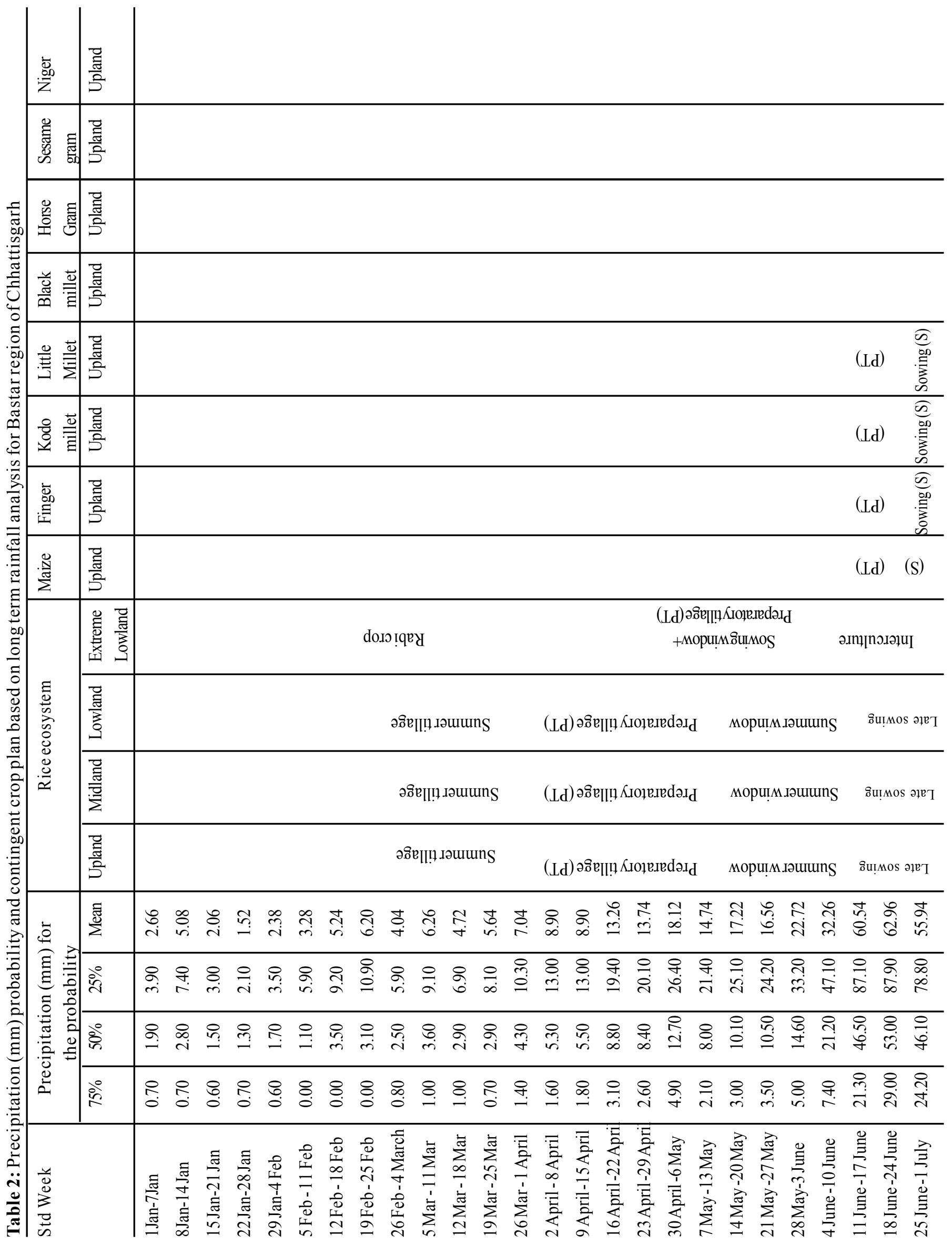




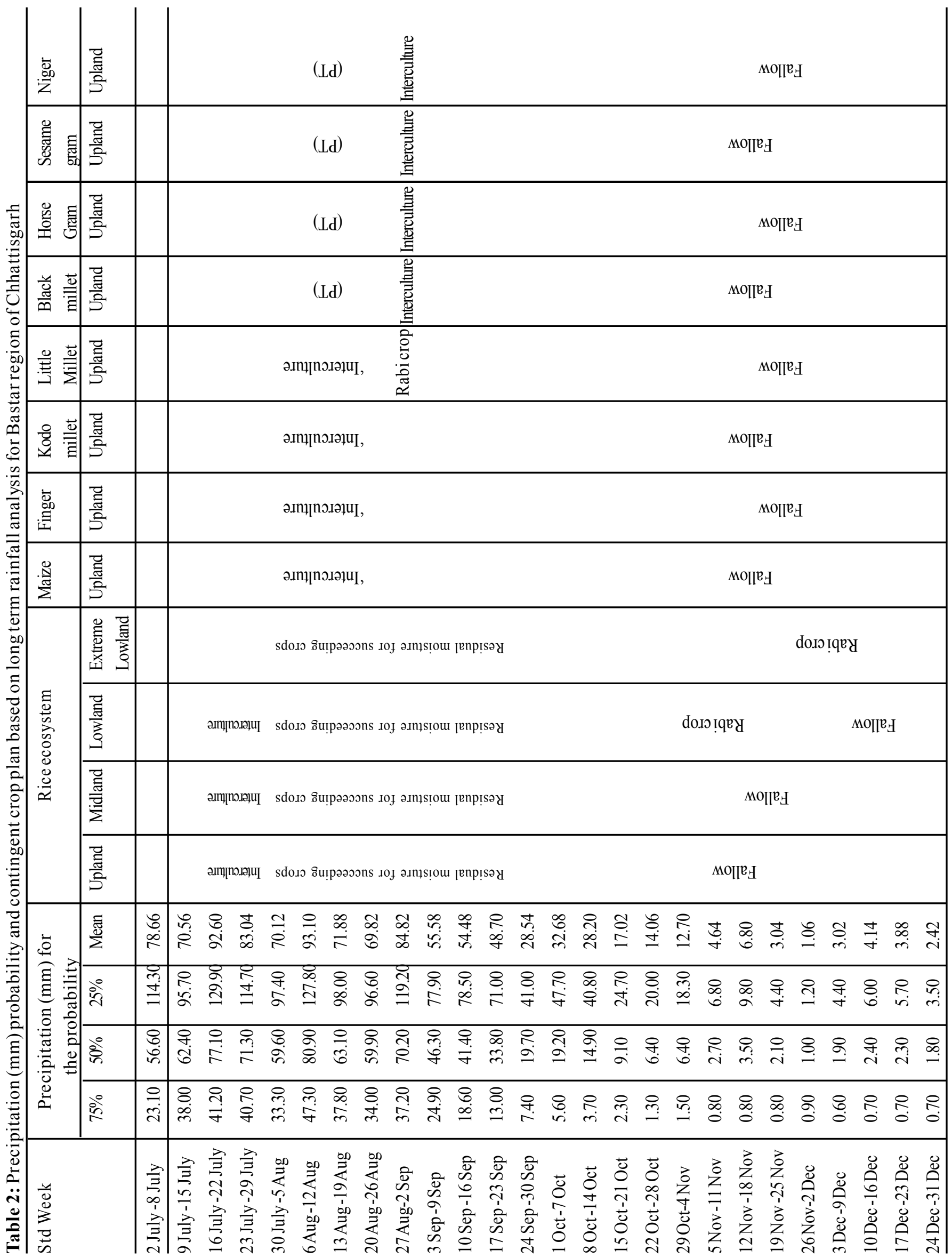


Table 3: Rainfall pattern and crop planning for deficit in kharif season rainfall (1986-2018)

\begin{tabular}{|c|c|c|c|c|c|c|c|c|c|c|c|}
\hline Crop & $\begin{array}{l}\text { Sowing to } \\
\text { harvesting } \\
\text { (days) }\end{array}$ & $\begin{array}{l}100 \% \\
\text { Rain }\end{array}$ & $\begin{array}{l}\text { Yield } \\
\text { potential } \\
\left(\mathrm{q} \mathrm{ha}^{-1}\right)\end{array}$ & $\begin{array}{l}25 \% \\
\text { Rain } \\
\text { deficit }\end{array}$ & $\begin{array}{l}\text { Yield } \\
\text { potential } \\
\left(\mathrm{qha}^{-1}\right)\end{array}$ & $\begin{array}{l}50 \% \\
\text { Rain } \\
\text { deficit }\end{array}$ & $\begin{array}{l}\text { Yield } \\
\text { potential } \\
\left(\mathrm{q} \mathrm{ha}^{-1}\right)\end{array}$ & $\begin{array}{l}75 \% \\
\text { Rain } \\
\text { deficit }\end{array}$ & $\begin{array}{l}\text { Yield } \\
\text { potential } \\
\left(\mathrm{qha}^{-1}\right)\end{array}$ & $\begin{array}{l}90 \% \\
\text { Rain } \\
\text { deficit }\end{array}$ & $\begin{array}{l}\text { Yield } \\
\text { potential } \\
\left(\mathrm{qha} \mathrm{a}^{-1}\right)\end{array}$ \\
\hline Upland (Paddy) & $100-110$ & 1053.48 & 12.00 & 522.32 & 8.90 & 511.78 & 5.53 & 262.21 & 4.22 & 129.05 & 2.19 \\
\hline Midland (Paddy) & $110-130$ & 1018.72 & 20.20 & 505.08 & 14.98 & 494.89 & 9.32 & 253.56 & 7.10 & 124.79 & 3.69 \\
\hline Lowland(Paddy) & $130-140$ & 1049.80 & 25.50 & 520.49 & 18.91 & 509.99 & 11.76 & 261.30 & 8.97 & 128.60 & 4.65 \\
\hline $\begin{array}{l}\text { Lowland } \\
\text { (Transplanting) }\end{array}$ & $135-150$ & 871.82 & 35.40 & 432.25 & 26.25 & 423.53 & 16.33 & 217.00 & 12.45 & 106.80 & 6.46 \\
\hline Maize & $90-105$ & 1011.23 & 45.70 & 501.37 & 33.89 & 491.26 & 21.08 & 251.70 & 16.07 & 123.88 & 8.34 \\
\hline Finger millet & $110-120$ & 1049.80 & 15.50 & 520.49 & 11.49 & 509.99 & 7.15 & 261.30 & 5.45 & 128.60 & 2.83 \\
\hline Kodo millet & $100-110$ & 1018.72 & 12.60 & 505.08 & 9.34 & 494.89 & 5.81 & 253.56 & 4.43 & 124.79 & 2.30 \\
\hline Little millet & $60-70$ & 748.68 & 5.50 & 371.20 & 4.08 & 363.71 & 2.54 & 186.35 & 1.93 & 91.71 & 1.00 \\
\hline Sorghum & $90-110$ & 1018.72 & 10.40 & 505.08 & 7.71 & 494.89 & 4.80 & 253.56 & 3.66 & 124.79 & 1.90 \\
\hline Blackgram & $90-105$ & 623.02 & 8.90 & 308.89 & 6.60 & 302.66 & 4.10 & 155.07 & 3.13 & 76.32 & 1.62 \\
\hline Horse gram & $90-105$ & 623.02 & 12.00 & 308.89 & 8.90 & 302.66 & 5.53 & 155.07 & 4.22 & 76.32 & 2.19 \\
\hline Sesame & $90-105$ & 626.06 & 6.70 & 310.40 & 4.97 & 304.14 & 3.09 & 155.83 & 2.36 & 76.69 & 1.22 \\
\hline Niger & $90-105$ & 529.92 & 7.20 & 262.73 & 5.34 & 257.44 & 3.32 & 131.90 & 2.53 & 64.92 & 1.31 \\
\hline Mean & 864.85 & 16.74 & 428.79 & 12.41 & 420.14 & 7.72 & 215.26 & 5.89 & 105.94 & 3.05 & \\
\hline Std Dev & 203.34 & 12.11 & 100.81 & 8.98 & 98.78 & 5.58 & 50.61 & 4.26 & 24.91 & 2.21 & \\
\hline SD error & 56.40 & 3.36 & 27.96 & 2.49 & 27.40 & 1.55 & 14.04 & 1.18 & 6.91 & 0.61 & \\
\hline
\end{tabular}

Maize, finger millet, kodo millet and little millet have wide window of fallow after kharif, that's why preparatory tillage and sowing were performed together between $11^{\text {th }}$ to $24^{\text {th }}$ June. Later, interculture operations took place in July and August. In case of blackgram, horsegram, sesame and niger, the lands were prepared without summer ploughing in mid-kharif season (August). Sowing of mid kharif crops just after preparatory tillage has been scaled up which is highly beneficial with probability of 75 and $50 \%$ rain $(>40 \mathrm{~mm})$ in mid-August. During this period, tillage operation should not be delayed one week and the tillage operation has been adjusted between 6 to $19^{\text {th }}$ August with prevailing rainfall pattern (Tang et al., 2005).

\section{Crop planning based on rainfall variability}

Rice ecosystem of the region is unique and varied according to land situations and cultivation practices. Summer tillage was performed from 9 to 14 SMW for midland and lowland which often receives nominal rainfall (4.04 to $8.90 \mathrm{~mm}$ per week). The ideal crop planning was proposed to sow rice during 15-25 May which reduced weed density drastically along faster seedling establishment compared to late sown rice (Table 2). This practice prolongs soil moisture to combat upcoming dry spells. Early direct deeded rice is conducive to early establishment and vulnerable to late season drought (Tuong et al., 2000).

To enhance the potentiality of millet crops under prevailing rainfall pattern the crop planning was adjusted with sowing in $25^{\text {th }}$ June to $1^{\text {st }}$ July (26 SMW) increased the yields. Pradhan et al. (2018) found that the finger millet and little millet take3-4 days to emerge, whereas kodo millet emerge in 8-10 days with 5-9 day advance in maturity under such prevailing rainfall if crops are sown early. Little millet matures in 75 days giving opportunity of second crops (horsegram and niger). Yadav et al. (2016) also suggested similar plan with rabi pulses and oilseeds grown on residual soil moisture. Kaur and Kaur (2016) projected different scenario for crop yields with changing rainfall pattern.

\section{Crop fitting ideas based on rainfall}

The rice growing eco-systems include months from June to November in kharif season, but rice is sown late (2030 June) due to normal onset of monsoon is first fortnight of June. The old concept was to sow the rice after onset of monsoon which could be consequence of poor germination under high soil moisture (Fig. 2). The crop planning was 

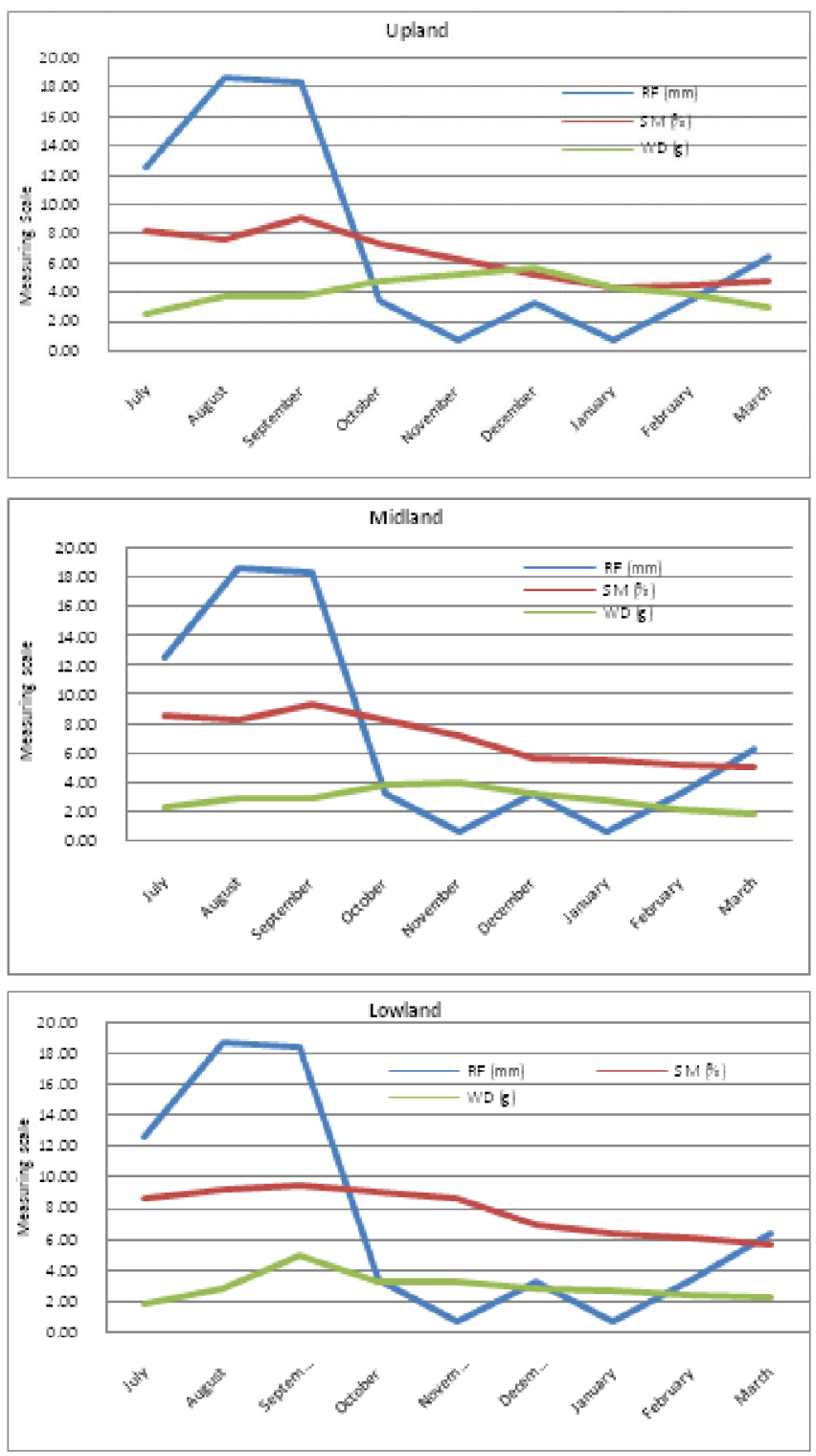

Fig.2: Rainfall (RF), Soil moisture (SM) and Dry weight $\mathrm{m}^{-2}$ (WD) under farming situations of Bastar region

advised to sow the rice with pre-monsoon shower during second fortnight of May. The May shown rice crop easily mitigated with $50 \%$ deficit rainfall under mid-land and lowland ecosystems. Millets were sown in second fortnight of June gave higher yield even rainfall deficit reached $75 \%$. But blackgram, horsegram, sesame and niger were very sensitive to high as well as low rainfall, for which the crop plan was reset with coupling preparatory tillage and sowing together (Table 3 ). This practice enhanced yields of these crops at 50 and $75 \%$ deficit rain as compared to existing practice.

Cropping window was reframed with the possibility of 75, 50 and $25 \%$ deficit rain for elevating yield. Rice yield was badly affected when rainfall deficit reached $50 \%$ for upland and midland ecosystems. Yield of maize and millets were drastically reduced under $70 \%$ deficit rain, whereas $25 \%$ deficit rain did not affect much to the yields. The condition became severe when rain deficit reached $75 \%$ or above and no contingent plan could adopt against such harsh situation (Table 3). Giri et al. (2017) found that rice yield of districts was as per predictions over long term data with meteorological variables in eastern Madhya Pradesh.

Rice ecosystem prolongs up to November and loss of yield was high under upland and midland when rainfall deficit reached $75 \%$ could be managed by preparedness through early dry aerobic seeding of rice in 15-20 May (Zacharias et al., 2014). The standard deviation of rainfall deficit was more significant at 25\% (100.81) and 50\% (98.78) affecting yield potential of crops in uplands. Standard errors were more pronounced with 50 and $25 \%$ rain deficit (27.40 and 27.96) on rainfed crops (Table 3 ).

\section{CONCLUSION}

The findings of the present study showed that rainfall variability influenced crop production with its intensity and magnitude. Cropping window analysis of decadal rainfall addressed the deficit in rainfall up to $90 \%$ reduced $80 \%$ production without crop planning. Yield of maize and millets were reduced $70 \%$ under $90 \%$ deficits in rainfall. On the other hand, $25 \%$ deficit rain did not affect more the yield of millets compared to $100 \%$ rain. Mainly upland crops were subjected to soil moisture stress with low rainfall during September and October. Hence, preparatory tillage and sowing have been suggested to perform together for utilization of sowing window. On the basis of 32-year rainfall analysis, probability of 75 and50\% rainfall have been projected as vulnerable to the vagaries of rainfall in all rainfed farming.

\section{ACKNOWLEDGEMENT}

Authors are thankful to GKMS Agromet project, S.G. College of Agriculture \& Research Station, IGKV, Jagdalpur for providing data and CRIDA, Hyderabad for basic analysis of weather parameters.

\section{REFERENCES}

Agarwal, A. (2000). Try capturing the rain: Briefing paper for members of parliament and state legislatures-an occasional paper. Center for Science and Environment, New Delhi, India.

Giri, A.K., Bhan, M. and Agrawal, K.K. (2017). District-wise wheat and rice yield predictions using meteorological 
variables in eastern Madhya Pradesh. J. Agrometereol., 19(4):366-368.

Jalota, S.K., Kaur, H., Ray, S.S., Tripathy, R., Vashisht, B.B. and Bal, S.K. (2013). Past and General Circulation Modeldriven future trends of climate change in Central Indian Punjab: ensuing yield of rice-wheat cropping system. Current Sci., 104(1): 105-110

Kaur, N. and Kaur, P. (2016). Projected climate change under different scenario in central region of Punjab, India. $J$. Agrometeorol., 18(1):88-92.

Kim. J., Shon. J., Lee, C.K., Yang, W., Yoon, Y., Yang, W.H., Kim, Y.G. and Lee, B.W. (2011). Relationship between grain filling duration and leaf senescence of temperate rice under high temperature. Field Crops Res., 122:207-13.

Kolli, R., Pant, G.B., Parthasarathy, B. and Sontakke, A. (1992). Spatial and sub-seasonal patterns of long-term trends of India summermonsoon rainfall. Int.J. Climatol., 12:257268.

Libiseller, C. and Grimall, A. (2002).Performance of partial MannKendall test for trend detection in the presence of covariates. Environmetrics, 13:71-84.

Pandey, S. and Bhandari, H. (2007). Drought: an overview. In: Pandey, S., Bhandari, H., Hardy, B. (Eds.), Economic Costs ofDrought and Rice Farmers Coping Mechanisms: Cross-Country Comparatives Analysis. International Rice Research Institute, Los Banos, Philippines, pp. 3142 .

Pradhan, A., Nag, S. K. and Mukherjee, S.C. (2018). Thermal requirement of small millets in Chhattisgarh plateau under rainfed cropping situation. J. Agrometeorol., 20 (3):244-245.

Rai, S.K. and Singh, K.A. (2009). Rainfall variability and probability for crop planning at Madhepura in Bihar. $J$. Agrometeorol., 11 (1):42-46.

Ramos, M.C. (2001). Rainfall distribution pattern and their change over time in a Mediterranean area. Theor. Appl. Climatol., 69:163-170.
Rao, G.S.L.H.V.P., Rao, G.G.S.N. and Rao, V.U.M. (2010). Climate Change and Agriculture over India. PHI Learning Private Limited, New Delhi, p328.

Rockstrom, J.and Falkenmark, M. (2000). Semi-arid crop production from a hydrological perspective-Gap between potential and actual yields. Crit.Rev. Plant Sci., 19 (4):319-346.

Sastri, A.S.R.A.S., Rai, S.K., Naidu, D. and Srivastava, A.K. (1999). Influence of climate parameters on productivity of rainfed rice - case study of Chattisgarh. In: Rice- in a variable climate,(Eds.Y.P. Abrol and SulochanaGadgil)., pp51-61.

Tripathi, P. (2012). Growth and production estimate in different agro-climatic regions of Uttar Pradesh, Final report of crop weather yield model, p12.

Yadav, M.K., Singh, R.S., Singh, K.K., Mall, R.K., Pastel, C., Yadav, S.K. and Singh, M.K. (2016). Assessment of climate change impact on pulse, oilseed and vegetable crops at Varanasi, India. J. Agrometeorol., 18(1):13-21.

Zacharias, M., Naresh Kumar, S., Singh, S.D., Swaroopa Rani, D.N. and Aggarwal, P.K. (2014). Assessment of impacts of climate change on rice and wheat in the Indo-Gangetic plains. J. Agrometeorol., 16(1):9-17.

Tang, J.L., Cheng, X.Q., Zhu, B. (2015). Rainfall and tillage impacts on soil erosion of sloping cropland with subtropical monsoon climate-a case study in central Sichuan Basin, China. J. Mount. Sci., 12(1): 134-144

Prasad, Y.G., Maheswari, Dixit, M., Rao, C.S., Sikka, A.K., Venkateswarlu, B., Sudhakar, N., Prabhu Kumar, S., Singh, A.K., Gogoi, A.K., Singh, A.K., Singh Y.V. and Mishra, A. (2014). Smart practices and technologies for climate resilient agriculture. Central Research Institute for Dryland Agriculture (ICAR), Hyderabad, p76.

Tuong, T.P., Pablico, P.P., Yamauchi, M., Confesor, R. and Moody, K. (2000). Increasing water productivity and weed suppression of wet seeded rice: effect of water management and rice genotypes. J. Exp. Agric., 36:119. 